\title{
PENINGKATAN KAPASITAS STUDI KELAYAKAN BISNIS PADA BUMDES DAN UMKM DI SUNGAI LANGKA KABUPATEN PESAWARAN
}

\author{
Muslimin ${ }^{1}$, Sri Hasnawati ${ }^{2}$, Nindya Puspitasari Dalimunthe ${ }^{3}$, Rialdi Azhar ${ }^{4}$ \\ 1,2,3,4Fakultas Ekonomi dan Bisnis,Universitas Lampung \\ Email : muslimin.1975@feb.unila.ac.id*
}

\begin{abstract}
ABSTRAK
The aim of this paper to describe how to enhance technical skill of Bumdes and SMEs in developing business financial feasibility analysis. Specifically, this activity aims to identify local economic potentials as a foundation to foster SME's growth by facilitating developing financial plan of their business. Participatory approach is used to transfer of knowledge of the training. As the pandemic situation, social media is used to account skill required. By using pre and post test to evaluate the training, the results show that the participants need to continuous training to apply the steps of feasibility study analysis. Even there is a progress in developing the materials technically, the score is still lower to transform the aspect financially. Financial literate dissemination is still needed to enhance financial skills of the participants.
\end{abstract}

Kata kunci: feasibility study, capacity, SME

\section{PENDAHULUAN}

Desa Sungai Lanka terletak di Kecamatan Gedong Tataan Kabupaten Pesawaran. Desa Sungai Langka terletak di daerah dataran tinggi di kaki Gunung Betung, dengan ketinggian $100-500 \mathrm{~m}$ dari atas permukaan laut, dan berjarak $7 \mathrm{~km}$ dari ibukota Kecamatan Gedong Tataan, $12 \mathrm{~km}$ dari ibukota Kabupaten Pesawaran, dan $20 \mathrm{~km}$ dari ibukota Provinsi Lampung. Luas pekon Sungai Langka sebesar $9 \mathrm{~km}^{2}$ atau $5 \%$ dai total luas Kecamatan Gedong Tataan. Secara administrative, letak Desa Sungai Langka berbatasan dengan Desa Bernung dan Negeri Sakti di sebelah Utara, Kurungan Nyawa di sebelah Timur, Hutan Negara/Gunung Betung di sebelah Selatan, Desa Wiyono dan PTPN VII Way Berulu di sebelah Barat.

Sumber mata pencharian utama penduduk Sungai Lanka adalah pertanian. Dari data luas lahan, penghasilan terbesar adalah dari tanaman kakao dengan luas $1.081 .04 \mathrm{Km}^{2}$. Selain hasil perkebunan berupa kakao, Desa Sungai Langka juga dikenal sebagai desa agrowista dengan hasil perkebunan berupa jeruk dan durian. . Dari aspek industri, jumlah industri kecil di Desa Sungai Langka menunjukan angka tertinggi pada jenis industri makanan dan kerajinan kayu.

Industri makanan relatif cukup berkembang di Desa Sungai Lanka, khususnya yang dijalankan oleh Ibu Rumah Tangga. Secara organisatoris, upaya ini dijalankan oleh UPPKS (Upaya Peningkatan Pendapatan Keluarga Sejahtera), dengan nama kelompok usaha Kenanga. Industri rumah tangga dibawah pembinaan Kelompok Kenanga memiliki produk yang beragam seperti bumbu pecel, susu kambing, dodol, manisan dan lain-lain. Pemasaran produk umumnya masih dalam wilayah desa, dengan sarana perdagangan 75 
warung kelontong dan 10 kedai makanan. Pangsa pasar lainnya adalah Kota Bandar Lampung, yang memiliki jarak realtif tidak terlalu jauh dengan Desa Sungai Lanka.

Industri berbasis rumah tangga ini memiliki potensi untuk dapat lebih dikembangkan. Namun demikian, pelaku usaha yang ada di Desa Sungai Langka tersebut belum dapat menuangkannya dalam secara tertulis, khususnya dalam bentuk analisa usaha yang memberikan ukuran layak atau tidak usaha tersebut dijalankan. Hal ini terjadi mengingat usaha-usaha tersebut masih dijalankan secara tradisional. Berdasarkan hal tersebut, UMKM dan Bumdes di Desa Sungai Lanka membutuhkan upaya penguatan kapasitas teknis penyusunan analisis studi kelayakan, sehingga UMKM di Desa Sungai Lanka memiliki pendokumentasian usaha yang dapat dipergunakan untuk mencari sumber pendanaan pihak ketiga, baik dari pemerintah maupun swasta.

\section{METODE}

Kegiatan ini dilakukan dengan metode ceramah dan praktik pengisian manual studi kelayakan. Manual studi kelayakan ini berisi materi-materi standar studi kelayakan yang umumnya dipergunakan, yang dikelompokan pada 3 kelompok utama yaitu; peluang usaha, target pasar, dan sumberdaya dan kapasitas usaha. Hasil dari proses pelatihan tersebut dilakukan melalui memberikan pre-test dan post-test kepada para peserta pelatihan.

\section{HASIL DAN PEMBAHASAN}

Pelatihan ini dilakukan di Desa Sungai Langka Kecamatan Gedung Tataan Kabupaten Pesawaran. Peserta pelatihan merupakan masyarakat yang memiliki usaha dan Bumdes Sungai Langka. Jumlah peserta pelatihan sebanyak dua puluh orang. Materi pelatihan yang diberikan kepada perserta pelatihan ini terkait dengan analisis studi kelayakan dan aspekaspeknya.

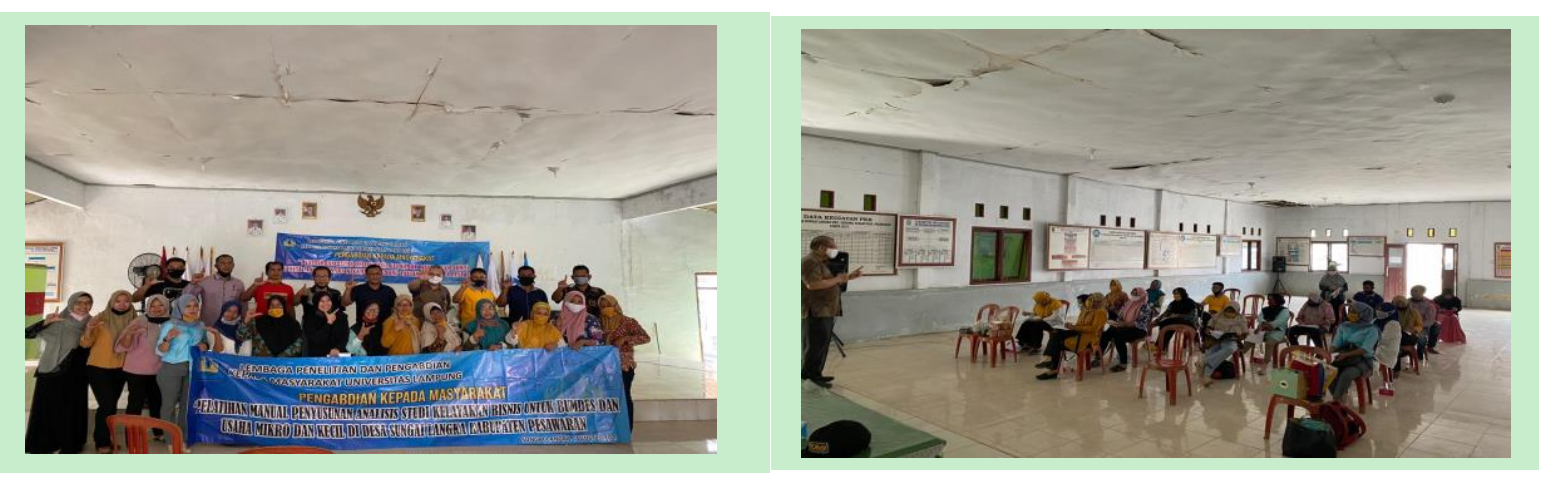

\section{Gambar 1: Peserta Pelatihan}

Peserta lebih banyak melakukan aktivitas mandiri dalam penyusunan analisis usahanya sesuai standar baku dalam analisis kelayakan usaha yang dipelajari diperguruan tinggi. 
Dalam proses pelatihan, tim pengabdian mendampingi peserta dalam penyusunan manual yang diberikan.

Berdasarkam pelatihan yang dilakukan, hasil pre-test dan post test pelatihan adalah sebagai berikut:

Tabel 1: Hasil Skor Pre-Test dan Post-Test Peserta Pelatihan

\begin{tabular}{|c|c|c|c|}
\hline Materi & Pre-Test & Post-Test & Perubahan \\
\hline Peluang Usaha & 32 & 52 & 62.50 \\
\hline Target pasar & 33 & 51 & 54.55 \\
\hline Sumberdaya dan kapasitas usaha & 33 & 51 & 54.55 \\
\hline
\end{tabular}

Sumber: Hasil Pre-Post Test Pelatihan

Secara umum, setelah dilakukan pre-test dan post-test, peserta pelatihan memiliki pengetahuan yang cukup tinggi dari aspek peluang usaha dan aspek-aspek lainnya. Namun demikian, yang paling krusial perlu diperkuat kembali adalah terkait dengan bagaimana menyusun proyeksi keuangan usaha. Dalam menyusun aspek ini, peserta pelatihan membutuhkan pendampingan lebih lanjut.

Pelatihan kemampuan SDM desa dalam bidang keuangan menjadi penting untuk dilakukan kepada para pelaku usaha di tingkat perdesaan. Hal ini sebagai dasar untuk dilakukannya kolaborasi dan pendirian asosiasi usaha di desa. Gallo et al (2018) menyebutkan inovasi model bisnis memiliki asosiasi dan kolaborasi yang kuat dapat menghasilkan solusi-solusi terhadap tantangan-tantangan sosial dan lingkungan. Hal ini diperkuat oleh Bai et al (2018), yang menunjukan usaha baru yang didirikan oleh warga yang kembali dari luar negeri meraih keunggulan kinerja internasional dari pengalaman entreprenur pendiri dengan jaringan internasional.

Kondisi ini secara empiris disampaikan oleh Neumer dan Santos (2018), yang melakukan riset pada adaptasi dan kreasi usaha baru yang sukses di Amerika Serikat Bagian Selatan, yang menunjukan kluster sosial mempengaruhi tipe usaha baru dan model bisnis yang dijalankan. Cheng et al (2018) juga menunjukan bagaimana investasi venture semakin berkembang pesat di China setelah mainstream kewirausahaan dan inovasi menjadi trend dalam meningkatkan industri tradisional dan mendukung aktivitas inovasi.

Dalam konteks pengembangan usaha, penting adanya pemahaman terhadap kondisi spesifik perusahaan dengan kondisi institusional yang mempengaruhi improvisasi usaha. Hal ini dinyatakan oleh Adomako et al (2018) yang melihat Efektifitas prilaku improvisasi dalam mendorong kesukesan persuahaan tergantung pada dukungan institusional. Dengan pemahaman yang baik terhadap kondisi tersebut, Teece (2018) menyebut aspek kapabilitas dalam mendinamisasi perusahaan menjadi faktor yang penting dalam implementasi inovasi model bisnis.

Keberadaan jaringan bisnis ventura akan meningkatkan arus informasi yang dapat bermanfaat bagi perusahaan. Parida et al (2018) melihat dengan semakin banyaknya informasi yang memperkuat struktur proses dalam perusahaan ventura, akan semakin meningkatkan realisasi penjualan perusahaan. Strukturisasi perusahaan ventura yang kuat diindikasikan dengan struktur proses yang mampu menyerap informasi-informasi tidak saja faktor ekonomi, namun juga nonekonomi. Hal inilah yang disarankan oleh Biloslavo et al 
(2018), yang merumuskan pentingnya partnership dengan publik, perusahaan partner dan customer, yang dapat memberikan perspektif analisa dimensi sustainabilitas ekonomi, sosial dan lingkungan secara berkesinambungan.

\section{KESIMPULAN}

Pelatihan ini memberikan peningkatan pemahaman masyarakat terhadap teknis penyusunan analisis usaha yang selama ini dijalankan oleh masyarakat, khususnya UMKM dan Bumdes. Namun demikian, aspek-askpek teknis penyusunan analisis usaha masih membutuhkan pendampingan lebih lanjut pada aspek kapasitas usaha, khususnya dalam hal kuantifikasinya dalam proyeksi keuangan.

\section{DAFTAR PUSTAKA}

--------, Gedung Tatatan Dalam Angka, 2019

-------, Pesawaran Dalam Angka 2019, Badan Pusat Statistik.

--------, UU No 6 Tahun 2014, Kemenkumham

Adomako, Samuel and R. A. Opoku, K. Frimpong. 2018. Entrepreneurs' Improvisational Behavior and New Venture Performance: Firm-Level and Institutional Contingencies. Journal of Business Research Vol. 83, pp. 10-18.

Bai, Wensong and C. Holmström-Lind, M. Johanson. 2018. Leveraging Networks, Capabilities and Opportunities for International Success: A Study on Returnee Entrepreneurial Ventures. Scandinavian Journal of Management Vol. 34, pp. 51-62.

Basuki, N., Suhardi, \& S. Sangadji, S. (2020). PENGELOLAAN KELAPA TERPADU ZERO WASTE DI DESA LEMBAH ASRI KECAMATAN WEDA SELATAN. Jurnal Abdimas Bina Bangsa, 1(2), 231-239. doi:10.46306/jabb.v1i2.36

Biloslavo, Roberto and C. Bagnoli, D. Edgar. 2018. An Eco-Critical Perspective on Business Models: The Value Triangle as an Approach to Closing the Sustainability Gap. Journal of Cleaner Production Vol. 174, pp. 746-762.

Cheng, Xiang and J. Gu, Z. Xu. 2018. Venture Capital Group Decision-Making with Interaction under Probabilistic Linguistic Environment. Knowledge-Based Systems, Vol. 140, pp. 82-91.

Gallo, Peter Jack and R. Antolin-Lopez, I. Montiel. 2018. Associative Sustain Able Business Models: Cases in the Bean-to-Bar Chocolate Industry. Journal of Cleaner Production Vol. 174, pp. 905-916.

Muhtarom, Nizaruddin, \& Aryan Eka Prastya Nugraha. (2020). PELATIHAN PEMBUATAN MEDIA UNTUK PEMBELAJARAN JARAK JAUH. Jurnal Abdimas Bina Bangsa, 1(1), 98-106. doi:10.46306/jabb.v1i1.19

Parida, Vinit and N. M. George, J. Wincent. 2018. Strategic Diagnosis of Information Processing Structures and Commercialization in New Ventures. Journal of Business Research, Vol. 85, pp. 83-90

Teece, David J. 2018. Business Models and Dynamic Capabilities. Long Range Planning, Vol. 51, pp. 40-49. 